\title{
POLYACRYLAMIDE GEL ELECTROPHORESIS (PAGE) OF WHOLE-CELL PROTEINS OF CUTANEOUS PROPIONIBACTERIUM SPECIES
}

\author{
K. M. NORDSTROM* \\ Institute of Dermatology, Department of Bacteriology, Homerton Grove, \\ London E9 6BX
}

\begin{abstract}
Summary. Polyacrylamide gel electrophoresis (PAGE) was applied to the study of whole-cell proteins of cutaneous propionibacteria in an attempt to characterise possible protein patterns that may be typical for strains isolated from acne skin. Isolates were obtained from the faces of 33 individuals aged 7-16 years. Some of these subjects had apparently normal healthy skin, whereas others had acne vulgaris of varying severity. Twenty-five facial isolates of Propionibacterium acnes and eight of $P$. granulosum were studied. A further seven axillary strains of $P$. avidum were included for purely taxonomic interest. No particular protein pattern was characteristic of an isolate from acne skin; in fact the $P$. acnes strains from all sources appeared to be identical.
\end{abstract}

\section{INTRODUCTION}

Propionibacterium acnes, $P$. granulosum and $P$. avidum are the most common resident anaerobes of the human skin surface (Kligman, Leyden and McGinley, 1976; McGinley, Webster and Leyden, 1978). After much confusion in the taxonomy of these organisms, the work of Johnson and Cummins (1972) finally established the validity of the three species. These workers found that $P$. acnes and $P$. avidum could each be divided into two serotypes, I and II, on the basis of cell-wall antigens, whereas $P$. granulosum has only one serotype. More recent reports suggest that intraspecies variation may occur in the cutaneous propionibacteria. It has been suggested that several biotypes of $P$. acnes differ in their ability to ferment various carbohydrates, but there does not appear to be agreement on the number of biotypes or on the most useful tests to perform. Pulverer and Ko (1973) reported that $P$. acnes could be divided into eight biotypes on the basis of fermentation of inositol, maltose, mannitol and sorbitol and claimed that 11 serotypes could be defined. On the other hand, Kishishita et al. (1979) were only able to confirm the existence of two serotypes which could be divided into five biotypes by fermentation tests with ribose, erythritol, and sorbitol. Similar biotyping schemes have not been applied to characterise possible strain variation in $P$. granulosum or $P$. avidum.

Received 10 Apr. 1984; accepted 6 May 1984.

*Present address and requests for reprints: Duhring Laboratories, Department of Dermatology, University of Pennsylvania Medical School, Medical Education Building, room D-230, 36th and Hamilton Wk., Philadelphia, PA 19104, USA. 
Polyacrylamide gel electrophoresis has been applied to the classification of microorganisms by many workers. Jackman (1982) and Jackman, Feltham and Sneath (1983) have applied numerical taxonomy to the analysis of PAGE patterns of coryneform bacteria. Results from studies of protein patterns can be shown to agree with those obtained by numerical taxonomy based on phenotypic tests and DNA hybridisation (Kersters and De Ley, 1975; Gross, Ferguson and Cummins, 1978; Owen and Jackman, 1982). Protein patterns and enzyme mobilities of the cutaneous propionibacteria have previously been examined by Gross et al. (1978) with an emphasis on taxonomy. Electrophoretic patterns were found to be distinctive for the three Propionibacterium species and their serotypes. The aim of the present study was to use PAGE to investigate possible intraspecies variation and to determine whether bacteria isolated from acne skin and apparently normal, healthy skin exhibited different protein patterns.

\section{MATERIALS AND METHODS}

Isolation and identification of strains. Twenty-seven strains of $P$. acnes, nine of $P$. granulosum and nine of $P$. avidum were studied. $P$. acnes VPI3706 and VPI0162, $P$. avidum VPI0589 and VPI0575 and $P$. granulosum VPI0507 were used as reference strains. Wild strains were isolated from the foreheads of subjects aged 7-16 years by the detergent scrub technique (Williamson and Kligman, 1965). These children had various degrees of acne graded as follows; $0=$ no visible signs of acne, $1=$ comedones only, $2=$ comedones and papules, $3=$ comedones, papules and pustules. The $P$. acnes wild strains were isolated from eight individuals aged 12 years or under and from 17 individuals over 12 years of age. Eleven strains were isolated from healthy skin, three from grade 1 acne, eight from grade 2 and three from grade 3 . The eight wild strains of $P$. granulosum were isolated from two individuals aged 12 or under and from six individuals older than 12 . One strain originated from normal healthy skin, three from grade 1 , and the remaining four from grade 2 acne. Strains of $P$. avidum were isolated, with swabs contained in Amies transport medium (Sterilin), from the axillae of two individuals aged 12 or under and from five older individuals.

The cultures were inoculated on to a medium consisting of tryptone soya broth $3 \%$, yeast extract $1 \%$, bacteriological agar $1.2 \%$ and Tween $800.5 \%$ (Weissman and Noble, 1980 ) and incubated for 4 days at $37^{\circ} \mathrm{C}$ in an atmosphere of $\mathrm{CO}_{2} 10 \%, \mathrm{H}_{2} 10 \%$ and $\mathrm{N}_{2} 80 \%$. The organisms may be presumptively identified on this medium according to their colony morphology which is similar to their morphology on casein-yeast-lactate-glucose agar (Marples and McGinley, 1974). Results were confirmed by biochemical tests according to McGinley et al. (1978).

Preparation of samples for studies on whole cell protein patterns. The bacteria were inoculated on to media as lawns and incubated anaerobically as described above. At the end of the incubation period $1 \mathrm{~g}$ wet weight of bacterial cells was suspended in $20 \mathrm{ml}$ of distilled water and washed by mixing followed by centrifugation at $19000 \mathrm{~g}$ for $10 \mathrm{~min}$. The cell pellet was resuspended in 5-10 drops of distilled water and then transferred into a glass vial suitable for sonication. The bacteria were disrupted by ultrasonication (MSE Instruments). The probe and attached vial were immersed in an icebath during sonication. A 6-min sonication period was found to yield the most protein; to prevent overheating this was performed in 2-min sessions, and the probe and attached vial were cooled in ice between each sonication session.

After sonication, 10 drops of the sample were added to 10 drops of sodium-dodecyl-sulphate (SDS) sample buffer containing $0.0625 \mathrm{MTris}-\mathrm{HCl}(\mathrm{pH} 6.8)$ with $\mathrm{SDS} 2 \%, 2$-mercaptoethanol $5 \%$ and glycerol $10 \%$. Chemicals were from Sigma Chemical Co., UK, or BDH Chemicals Ltd, UK. The preparation was then boiled in a waterbath for $10 \mathrm{~min}$. After treatment, the samples were cooled and centrifuged at $38000 \mathrm{~g}$ at $4^{\circ} \mathrm{C}$ for $30 \mathrm{~min}$.

Polyacrylamide gel electrophoresis ( $P A G E$ ) was used according to the method of Laemmli (1970) with minor modifications. Slab gels, $2.7 \mathrm{~mm}$ thick, were prepared in a multiple gel casting mould (Universal Scientific Ltd, UK). Separation gels were stored overnight before casting and adding of the stacking gel in a Pharmacia Gel Casting Apparatus, GSC-8 (Pharmacia Fine 
Chemicals, Sweden). Wells $8 \mathrm{~mm}$ deep and $7.5 \mathrm{~mm}$ wide were made with plastic well-formers (Pharmacia).

The separation gel consisted of $10 \%$ polyacrylamide prepared from a stock solution of $30 \%$ acrylamide and $0.8 \%$ bis-acrylamide (Sigma), which was filtered and stored at $4{ }^{\circ} \mathrm{C}$. Final concentrations of components were $0.375 \mathrm{M}$ Tris- $\mathrm{HCl}(p \mathrm{H} 8.8)$ and SDS $0.1 \%$. Polymerisation was achieved with $0 \cdot 1 \% \mathrm{v} / \mathrm{v} \mathrm{N}^{\prime} \mathrm{N}^{\prime} \mathrm{N} \mathrm{N}$ - tetramethyl ethylenediamine (TEMED) and $5 \% \mathrm{v} / \mathrm{v}$ of a $10 \%$ solution of ammonium persulphate. The stacking gel consisted of $5 \%$ acrylamide (from the stock solution) containing $0 \cdot 125 \mathrm{M}$ Tris- $\mathrm{HCl}(p \mathrm{H} \mathrm{6.8)}$ and SDS $0 \cdot 1 \%$. The protein concentration was assayed by the method of Lowry et al. (1951), and $10 \mu \mathrm{l}$ of a $10 \mathrm{mg} / \mathrm{ml} \mathrm{sample} \mathrm{was} \mathrm{applied} \mathrm{to}$ the wells. Bromophenol blue was used as a tracking dye.

Gels were run in a Pharmacia Gel Electrophoresis Apparatus GE-4 at 50 volts for $16 \mathrm{~h}$. The electrode buffer consisted of $0.0025 \mathrm{M}$ Tris, $0.192 \mathrm{~m}$ glycine and SDS $0 \cdot 1 \%, p \mathrm{H} 8 \cdot 3$. The power supply was a Pharmacia EPS $400 / 500$. The gels were stained with Coomassie Brilliant Blue R-250 (Sigma) $0 \cdot 05 \%$ in water: methanol:trichloroacetic acid $(5: 5: 1, \mathrm{v} / \mathrm{v} / \mathrm{w})$ overnight and then destained in water:methanol:trichloroacetic acid $(38: 2: 3, \mathrm{v} / \mathrm{v} / \mathrm{w})$ until the background was clear.

Comparison of protein patterns. The average similarity between two strains was assessed by the coefficient of Dice (1945), whereby

$$
\text { average similarity }=\frac{\text { number of matching bands } \times 2}{\text { total number of bands in both strains }}
$$

The calculation of similarity was based on a visual comparison and all strains were run several times to confirm the results.

\section{RESULTS}

The $27 P$. acnes strains had very similar protein patterns (fig. 1). This was true for organisms isolated from individuals of different ages and with various degrees of acne. Similarly, the $P$. granulosum strains isolated from individuals with acne were not distinct from the other strains of this species. $P$. acnes and $P$. avidum could be distinguished from $P$. granulosum, but the patterns for $P$. acnes and $P$. avidum were very similar (fig. 2). P. acnes serotypes I and II (strains VPI3706 and VPI0162) appeared to be nearly identical by this technique (table) and only differed by possibly one or two bands. Serotypes I and II of P. avidum (strains VPI0575 and VPI0589) also resembled each other closely; they differed by only five or six bands (table). Variation was evident in the wild strains of $P$. avidum, but the differences were not sufficient to distinguish one or the other serotype.

The pattern given by strains of $P$. granulosum was the most distinct of all the three species tested and characteristically presented with a set of broad bands (fig. 2). More

TABLE

Average percentage similarity $(\% S)$ of cutaneous Propionibacterium spp.

\begin{tabular}{llc}
\hline \multicolumn{2}{c}{ Strains compared } & $\% \mathrm{~S}$ \\
\hline P. acnes VPI3706 & P. acnes VPI0162 & $99-100$ \\
P. avidum VPI0575 & P. avidum VPI0589 & 86 \\
P. acnes VPI3706 & P. granulosum VPI0507 & 76 \\
P. acnes VPI3706 & P. avidum VPI0575 & 79 \\
P. acnes VPI3706 & P. avidum VPI0589 & 75 \\
$P$. avidum VPI0575 & P. granulosum VPI0507 & 51 \\
P. avidum VPI0589 & P. granulosum VPI0507 & 51 \\
\hline
\end{tabular}




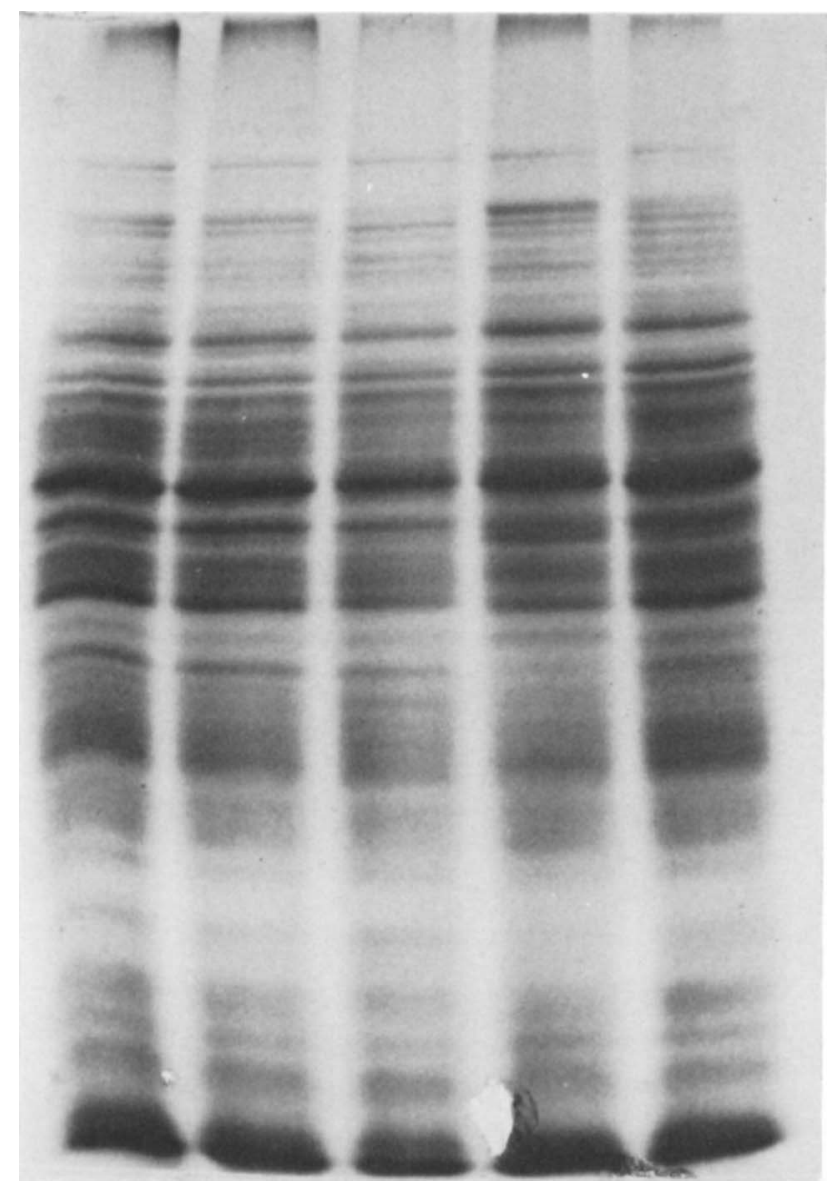

\section{$\begin{array}{llll}\text { VPI } & \text { 75B } & \text { 71A } & \text { 208A }\end{array}$}

FIG. 1.-Electrophoresis of proteins extracted from one reference and four wild strains of $P$. acnes.

variation in band pattern occurred among wild strains of $P$. granulosum than among isolates of $P$. acnes or $P$. avidum.

The estimated average similarity of $P$. acnes strains to the serotypes I and II of $P$. avidum and $P$. granulosum was of the order of $79 \%, 75 \%$ and $76 \%$ respectively (table). A comparison was made only with $P$. acnes VPI3706 because the two serotypes of $P$. acnes were $99-100 \%$ similar. Interestingly, $P$. acnes serotype I (VPI3706) resembled serotype I of $P$. avidum (VPI0575) more than it did serotype II of $P$. avidum (VPI0589) which is in accord with previous data on cell-wall analysis of these bacteria (Johnson and Cummins, 1972). However, the estimated similarity of P. granulosum with serotypes of $P$. avidum was only $51 \%$.

\section{Discussion}

The 25 wild strains of $P$. acnes isolated from individuals $7-16$ years old without acne or with various degrees of acne did not differ in their whole-cell protein patterns. 


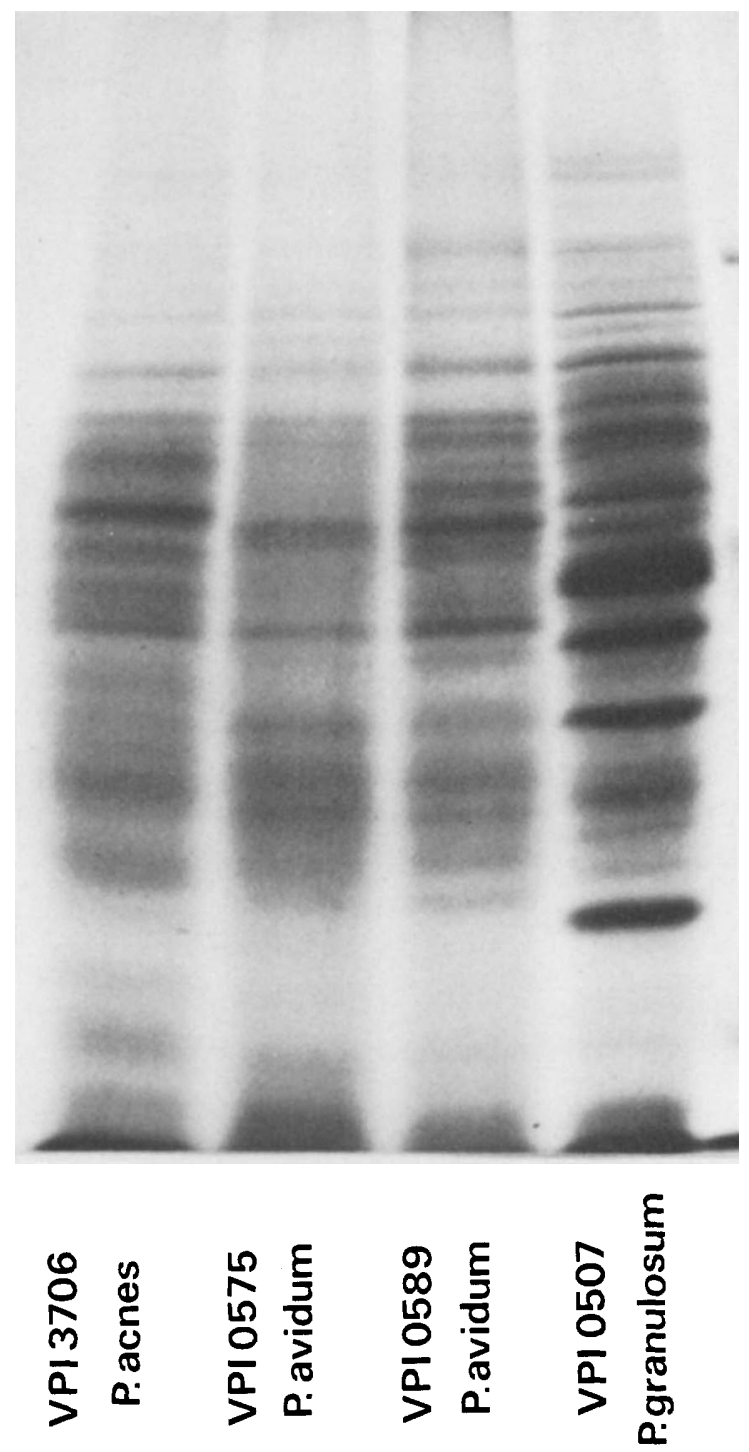

FIG. 2.-Electrophoresis of proteins showing patterns of $P$. acnes, $P$. avidum and $P$. granulosum.

The $P$. granulosum strains showed more variation in band pattern in general, and thus no correlation could be made with reference to acne. This preliminary study did not reveal any major differences between the strains, but a more detailed study, perhaps using two-dimensional PAGE together with densitometric scanning of gels, might be necessary to detect any specific proteins involved in virulence. PAGE studies on enzyme activity of strains isolated from acne and non-acne skin may also be of interest in the future.

This study was not primarily taxonomic but the results are in broad agreement with the work of Johnson and Cummins (1972) and Gross et al., (1978). P. acnes and P. avidum resembled each other more closely than $P$. granulosum. However, when the average similarity between the species was calculated, $P$. acnes and $P$. granulosum were 
more similar than has previously been reported (Johnson and Cummins 1972; Gross et al., 1978). The discrepancies may be attributable to differences in techniques, such as the treatment of samples with SDS. It is clearly important to consider technical details in such studies. For example, occasionally faint or diffuse bands were encountered and these were thought to be related to the mechanical disruption of cells by sonication. It was assumed that some proteins may be destroyed during this procedure. However, these bacteria will not yield enough protein when treated with lysozyme or cold acetone or by simple boiling with SDS. Therefore, no satisfactory alternative to mechanical disruption appears to be presently available.

The advice of Professor W. C. Noble, Dr P. J. H. Jackman and Dr O. S. Kinsman is gratefully acknowledged. This work was funded by a grant from Vick International, UK.

\section{REFERENCES}

Dice L R 1945 Measures of the amount of ecologic association between species. Ecology 26:297-302.

Gross C S, Ferguson D A, Cummins C S 1978 Electrophoretic protein patterns and enzyme mobilities in anaerobic coryneforms. Applied and Environmental Microbiology 35:1102-1108.

Jackman P J H 1982 Classification of Corynebacterium species from axillary skin by numerical analysis of electrophoretic protein patterns. Journal of Medical Microbiology 15:485-492.

Jackman P J H, Feltham R K A, Sneath P H A 1983 A program in BASIC for numerical taxonomy of micro-organisms based on electrophoretic protein patterns. Microbios Letters 23:87-98.

Johnson J L, Cummins C S 1972 Cell wall composition and deoxyribonucleic acid similarities among the anaerobic coryneforms, classical propionibacteria and strains of Arachnia propionica. Journal of Bacteriology 109: 1047-1066.

Kersters K, De Ley J 1975 Identification and grouping of bacteria by numerical analysis of their electrophoretic protein patterns. Journal of General Microbiology 87:333-342.

Kishishita M, Ushijima T, Ozaki Y, Ito Y 1979 Biotyping of Propionibacterium acnes isolated from normal human facial skin. Applied and Environmental Microbiology 38:585-589.

Kligman A M, Leyden J J, McGinley K J 1976 Bacteriology. Journal of Investigative Dermatology 67:160-168.

Laemmli U K 1970 Cleavage of structural proteins during the assembly of the head of bacteriophage T4. Nature 227:680-685.

Lowry O H, Rosebrough N J, Farr A L, Randall R J 1951 Protein measurement with the folin phenol reagent. Journal of Biological Chemistry 193:265-275.

Marples R R, McGinley K J 1974 Corynebacterium acnes and other anaerobic diphtheroids from human skin. Journal of Medical Microbiology 7:349-357.

McGinley K J, Webster G F, Leyden J J 1978 Regional variations of cutaneous propionibacteria. Applied and Environmental Microbiology 35:62-66.

Owen R J, Jackman P J H 1982 The similarities between Pseudomonas paucimobilis and allied bacteria derived from analysis of deoxyribonucleic acids and electrophoretic protein patterns. Journal of General Microbiology 128:2945-2954.

Pulverer G, Ko H L 1973 Fermentative and serological studies on Propionibacterium acnes. Applied and Environmental Microbiology 25:222-229.

Weissmann A, Noble W C 1980 Photochemotherapy of psoriasis: effect on bacteria and surface lipids on uninvolved skin. British Journal of Dermatology 102:185-193.

Williamson P, Kligman A M 1965 A new method for the quantitative investigation of cutaneous bacteria. Journal of Investigative Dermatology 45:498-503. 